\title{
A novel transposon construct expressing PhoA with potential for studying protein expression and translocation in Mycoplasma gallisepticum
}

Indu S Panicker ${ }^{1}$, Anna Kanci', Chien-Ju Chiu', Paul D Veith², Michelle D Glew², Glenn F Browning ${ }^{1}$ and Philip F Markham ${ }^{1 *}$

\begin{abstract}
Background: Mycoplasma gallisepticum is a major poultry pathogen and causes severe economic loss to the poultry industry. In mycoplasmas lipoproteins are abundant on the membrane surface and play a critical role in interactions with the host, but tools for exploring their molecular biology are limited.

Results: In this study we examined whether the alkaline phosphatase gene (phoA) from Escherichia coli could be used as a reporter in mycoplasmas. The promoter region from the gene for elongation factor Tu (Ituf) and the signal and acylation sequences from the v/hA1.1 gene, both from Mycoplasma gallisepticum, together with the coding region of phoA, were assembled in the transposon-containing plasmid pISM2062.2 (pTAP) to enable expression of alkaline phosphatase (AP) as a recombinant lipoprotein. The transposon was used to transform M. gallisepticum strain S6. As a control, a plasmid containing a similar construct, but lacking the signal and acylation sequences, was also produced (PTP) and also introduced into M. gallisepticum. Using a colorimetric substrate for detection of alkaline phosphatase activity, it was possible to detect transformed M. gallisepticum. The level of transcription of phoA in organisms transformed with PTP was lower than in those transformed with PTAP, and alkaline phosphatase was not detected by immunoblotting or enzymatic assays in pTP transformants, eventhough alkaline phosphatase expression could be readily detected by both assays in pTAP transformants. Alkaline phosphatase was shown to be located in the hydrophobic fraction of transformed mycoplasmas following Triton X-114 partitioning and in the membrane fraction after differential fractionation. Trypsin proteolysis confirmed its surface exposure. The inclusion of the VIhA lipoprotein signal sequence in PTAP enabled translocation of PhoA and acylation of the amino terminal cysteine moiety, as confirmed by the effect of treatment with globomycin and radiolabelling studies with $\left[{ }^{14} \mathrm{C}\right]$ palmitate. PhoA could be identified by mass-spectrometry after separation by twodimensional electrophoresis.

Conclusion: This is the first study to express PhoA as a lipoprotein in mycoplasmas. The pTAP plasmid will facilitate investigations of lipoproteins and protein translocation across the cell membrane in mycoplasmas, and the ease of detection of these transformants makes this vector system suitable for the simultaneous screening and detection of cloned genes expressed as membrane proteins in mycoplasmas.
\end{abstract}

Keywords: Mycoplasma gallisepticum, Lipoprotein, Membrane protein, Reporter gene, phoA, Alkaline phosphatase

\footnotetext{
* Correspondence: pmarkham@unimelb.edu.au

'Asia-Pacific Centre for Animal Health, Faculty of Veterinary Science, The

University of Melbourne, Parkville, VIC 3010, Australia

Full list of author information is available at the end of the article
} 


\section{Background}

Mycoplasmas are prokaryotes in the class Mollicutes and are characterised by the absence of a cell wall [1]. Mycoplasmas cause disease in a number of animal species and are able to survive and persist in the face of host defences, even though they possess a relatively small genome and are bounded by a single protective plasma membrane. The recent chemical synthesis and cloning of whole mycoplasma genomes has also drawn attention to the possibility of creating synthetic cells and genetic manipulation of the smallest bacterial genomes [2,3]. The proteins within the single limiting membrane of mycoplasmas fulfill many of the critical functions related to morphology, nutrient transport, environmental adaptation and colonisation of the host [4].

Many of the surface proteins of mycoplasmas are amphiphilic and/or lipid modified and some have been shown to be components of solute transport systems or involved in antigenic variation and adherence, while the functions of many others remain unknown [5-7]. Mycoplasmas possess an unusually large number of lipoproteins, which are anchored to the cell membrane by a lipid moiety, with the polypeptide moiety exposed on the cell's outer surface [8]. Lipoprotein signal peptides are cleaved by signal peptidase II at a conserved motif preceding the amino terminal cysteine of the mature lipoprotein. The significance of mycoplasma lipoproteins in interactions with the host emphasises the need to better understand how they are processed, and the mechanisms controlling their expression [4].

Mycoplasma gallisepticum is a major poultry pathogen, causing chronic respiratory disease in chickens, infectious sinusitis in turkeys and conjunctivitis in house finches $[9,10]$. It has a worldwide distribution and causes severe economic losses in the poultry industry. Vaccination of the flock is a necessity to control mycoplasmosis in commercial poultry farms. The live vaccines in use at present are F strain, 6/85 and ts-11 [11]. Although effective and widely used at present, these vaccines could be modified to act as vaccine vectors to deliver other antigens and thus be the basis of multivalent vaccines.

Although the genome of $M$. gallisepticum strain $\mathrm{R}_{\text {low }}$ has been sequenced [12], the lack of genetic systems for mycoplasmas in general impedes our ability to study their molecular biology. The use of UGA as a tryptophan codon in mycoplasmas also makes it tedious to use heterologous hosts such as Escherichia coli for expression and characterisation of cloned mycoplasma sequences [13]. Molecular tools such as reporter gene systems suitable for studying lipoprotein processing and expression in mycoplasmas are necessary.

The E. coli ß-galactosidase gene (lacZ) has been used to identify gene promoters and detect genetic regulatory elements in M. gallisepticum and Acholeplasma species
$[14,15]$, and as a reporter gene in combination with the vlhA 1.1 promoter in M. gallisepticum S6 [16]. A major drawback of the use of $\beta$-galactosidase $(ß-\mathrm{Gal})$ as a reporter is its limited ability to pass through the bacterial cytoplasmic membrane [17]. When the gene for an exported protein is fused to $l a c Z$, the hybrid protein is membrane bound and such proteins have very low $ß$ galactosidase activity [18]. Green fluorescent protein (GFP) has been used to identify promoter sequences in DNA libraries of Mycoplasma pneumoniae and Mycoplasma genitalium in E. coli [19], but GFP could not be detected following transformation in M. gallisepticum [20]. The chloramphenicol acetyl transferase (CAT) gene has also been used as a selectable marker in M. pneumoniae using a modified $\mathrm{Tn} 4001$ transposon [21].

The phoA gene codes for the E. coli periplasmic alkaline phosphatase (AP), and is active when exported across the cytoplasmic membrane into the periplasmic space [22-24]. Functional alkaline phosphatase is a dimer of two identical subunits and each subunit contains two intramolecular disulfide bridges. The amino-terminal signal sequence is cleaved upon translocation across the cytoplasmic membrane, and the mature PhoA is folded into an active conformation after export to the periplasmic space. Disulfide bond formation is followed by folding into monomers and then conversion to the active dimer conformation [25]. Enzymatic activity of PhoA fusion proteins depends on the presence of an export sequence and this principle has been used in developing reporter vectors to determine membrane protein topology and to facilitate identification of genes involved in bacterial virulence [26].

The aim of this study was to evaluate whether the $E$. coli phoA gene was suitable for use as a reporter gene to investigate gene expression and protein processing in mycoplasmas, using a construct incorporating signal sequences from the M. gallisepticum VlhA1.1 lipoprotein and the ltuf promoter to express PhoA as a membrane-associated lipoprotein.

\section{Results}

\section{Construction of plasmid ItufacyphoA (pTAP)}

The elongation factor $\mathrm{Tu}$ promoter region of $277 \mathrm{bp}$ (ltuf) (GenBank accession: X16462) and the leader sequence of the vlhA1.1 gene (GenBank accession: U90714) from $M$. gallisepticum were originally amplified by PCR from the genomic DNA of M. gallisepticum strain S6 and ligated into the pISM2062.2lac [14] vector to produce the ltufsiglac construct [20]. The ltuf promoter region was amplified from $M$. gallisepticum genomic DNA by PCR using the LNF and TSR oligonucleotide primers (Table 1), and the vlhA export signal sequence of $51 \mathrm{bp}$ was amplified from $M$. gallisepticum genomic DNA using the TSF and LBR primers 
Table 1 Oligonucleotides used in this study

\begin{tabular}{|c|c|}
\hline Oligonucleotide & Sequence $\left(5^{\prime}-3^{\prime}\right)$ \\
\hline LNF & gcggccgcTTAAGGGTGTAGTTCAATGG \\
\hline TSR & GTITITCTCTTCATTITITAAATATTTC \\
\hline TSF & GAAATATTTAAAAAAATGAAGAGAAAAAAC \\
\hline LBR & ggatcCCCAAACGAACCAATACC \\
\hline$\underline{\text { LTNF }}$ & gccgcggccGCTITAGGGGTGTAGTTCAATG \\
\hline$\underline{S B R}$ & TGTAGTACAACTAGCTGCAGCTAACATTACAAAgGAtCCAATACCTAAT \\
\hline AXPF & TTAGCTGCAGCTAGTTGTACTACACCTGTTCTAGAAAACCGGGCT \\
\hline PBgR & CCGaGATctaAAAGGACTGttaTATGGCCTTTTATTTTATTTCAGCCCCAGA \\
\hline LTPR & CGGTTTCTAGAACAGGCATTTITTTAAATATTTC \\
\hline LTPF & GAAATATTTAAAAAAATGCCTGTTCTAGAAAAC \\
\hline PBaR & CTITTggatcctaTTATTCAGCCCCAGAGC \\
\hline IRF & GGCCGgGATCAAGTCCGTATTATTGTGTAAAAGTgCtaGc \\
\hline IRR & ggCCgCtaGcACTTITACACAATAATACGGACTTGATCcC \\
\hline $\mathrm{GmF}$ & CCAAGAGCAATAAGGGCATAC \\
\hline GmR & ACACTATCATAACCACTACCG \\
\hline PRTF & ACGAAAAAGATCACCCAACG \\
\hline PRTR & GATCCTITTCCGCCTITTC \\
\hline $\mathrm{HLF}$ & TGGTAAGTTAAACGGGATCG \\
\hline HMR & AATGAACCAGTGATTGTTGGA \\
\hline UBR & GCAGTAATATCGCCCTGAGC \\
\hline
\end{tabular}

Lower case indicates changes made to introduce restriction endonuclease cleavage sites and bold lettering indicates the stop codons.

(Table 1). These two products were then joined by overlap extension PCR using the primers LNF and LBR. The resultant PCR product was ligated into pGEM-T (Promega) following the manufacturer's instructions. The ltuf promoter and $v$ lhA export signal sequence (ltufsig) region was excised from pGEM-T by digestion with NotI and $B a m H I$ and ligated into similarly digested pISM2062.2lac to generate pISM2062.2ltufsiglac. Digestion of pISM2062.2lac with NotI and BamHI resulted in the loss of one inverted repeat region (IR) in the insertion sequence of the transposon.

The ltuf promoter and the vlhA1.1 signal sequence from pISM2062.2ltufsiglac were amplified by PCR and used to create the ltufacyphoA construct. The ltuf promoter, vlhA1.1 signal and acylation sequence were amplified from pISM2062.2ltufsiglac as a single $369 \mathrm{bp}$ product using the primers LTNF and SBR (Table 1). The NotI cleavage site was included in the LTNF primer and the $v$ lhA signal sequence for lipoprotein export and acylation was included in the SBR primer. The phoA gene (1335 bp) was amplified from the plasmid pVM01:: TnphoA [27] using the primers AXPF and PBgR (Table 1). TnphoA encodes alkaline phosphatase without the export signal sequence and first five amino acids of the mature protein [24,28]. The 369 bp and 1335 bp PCR products were joined using overlap extension PCR to produce a $1693 \mathrm{bp}$ product using the LTNF and $\mathrm{PBgR}$ primers (Figure 1A). The $1693 \mathrm{bp}$ fragment was purified from a $1 \%$ agarose gel after electrophoresis using the Qiaex gel extraction kit (Qiagen) and ligated into pGEM-T following the manufacturer's instructions. An E. coli transformant containing a plasmid of the expected size was selected and the insert DNA sequence confirmed using BigDye terminator v3.1 cycle sequencing (Perkin Elmer Applied Biosystems) and the M13 universal primer sites of the vector. The DNA insert was released from the pGEM-T vector by digestion with NotI and BglII, gel purified using the Qiaex gel extraction kit (Qiagen) and ligated into NotI and BamHI digested pISM2062.2lac [14], resulting in pISM2062.2ltufacyphoA.

The first $26 \mathrm{bp}$ of the IS256 element, the IR region that was deleted during NotI-BamHI digestion of the pISM2062.2 vector, was restored by inserting a $40 \mathrm{bp}$ double stranded linker oligonucleotide, produced by annealing IRF and IRR, into the NotI cleavage site of the construct. The linker IRF oligonucleotide contained a mutation at the sixth base ( $\mathrm{C}$ to $\mathrm{G}$ ) from the $5^{\prime}$ end to inactivate the NotI cleavage site, and included an NheI cleavage site at the 3 ' end. IRF and the complementary IRR oligonucleotide were annealed by mixing them at equimolar ratios and heating to $50{ }^{\circ} \mathrm{C}$ for $1 \mathrm{~min}$, then slowly cooling at $1{ }^{\circ} \mathrm{C} / \mathrm{min}$ to $10{ }^{\circ} \mathrm{C}$. The double stranded linker had 4 base $5^{\prime}$ overhangs at each end to facilitate ligation to NotI digested pISM2062.2ltufacyphoA, resulting in NheI and NotI cleavage sites, and 


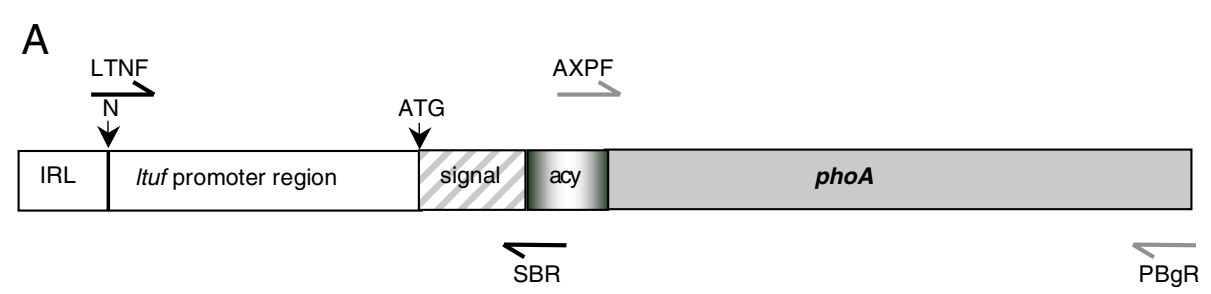

B

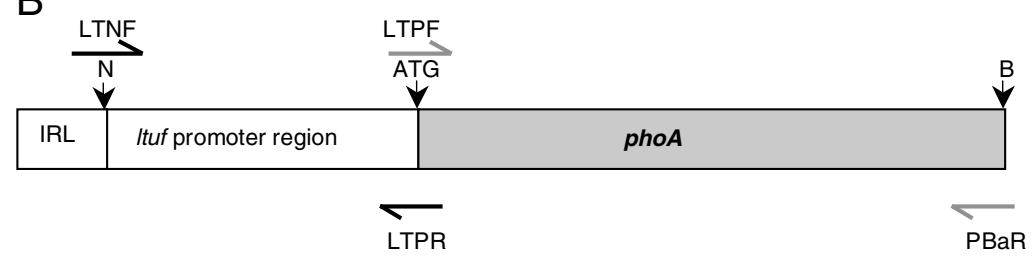

Figure 1 Schematic representation of $p h o A$ constructs. A. The different sections, including the ltuf promoter, the signal sequence, the acylation sequence and the phoA gene, were combined by overlap extension PCR as described in the text and ligated between the Notl and BamHI sites in pISM2062.2. The site of the IR oligonucleotide linker is shown. The positions of the oligonucleotide primers (Table 1) are also shown. B. The construct produced containing only the Ituf promoter and phoA gene. IRL: inverted repeat oligonucleotide linker, N: Notl cleavage site, B: BamHI cleavage site, ATG: translational start codon.

yielding the pISM2062.2ltufacyphoA vector (pTAP) with the modified IR region.

\section{Construction of plasmid ItufphoA (pTP)}

The pISM2062.2ltufphoA vector (pTP), which did not contain either the vlhA1.1 signal sequence or the acylation sequence of the PTAP plasmid, was also generated. The LTNF and LTPR primers were used to amplify the 305 bp ltuf promoter region, whilst the phoA gene was amplified using primers LTPF and PBaR. The PCR products were purified and joined by overlap extension PCR using primers LTNF and PBaR, which included Not $\mathrm{I}$ and BamHI sites, respectively (Figure 1B). The resultant PCR product of $1640 \mathrm{bp}$ was gel purified, ligated into pGEM$\mathrm{T}$ and the DNA sequence confirmed as described above. The ltufphoA was released from pGEM-T and ligated to similarly digested pISM2062.2lac, resulting in the plasmid pTP, and the IR oligo adaptor then inserted into the NotI cleavage site as described above.

\section{Transformation of $M$. gallisepticum with alkaline phosphatase expression constructs and detection of transformants}

Both pTP and pTAP plasmids were used to transform M. gallisepticum cells by electroporation. Transformant colonies were observed on MA plates containing gentamicin within 4 days, and colonies picked and grown in MB with gentamicin added. The presence of the gentamicin gene was confirmed by the amplification of a $223 \mathrm{bp} \mathrm{PCR} \mathrm{product} \mathrm{using} \mathrm{the} \mathrm{oligonucleotide} \mathrm{primers}$ $\mathrm{GmF}$ and $\mathrm{GmR}$. The genomic location of the transposon in each of the mycoplasma transformants was predicted following genomic DNA sequencing and BLAST searching the M. gallisepticum $\mathrm{R}_{\text {low }}$ genome (Table 2).
The M. gallisepticum-pTAP transformant colonies on MA plates stained blue following addition of the substrate BCIP/NBT. A strong blue colour development in $10 \mathrm{~min}$ was found to indicate transformant colonies, whilst a light blue colour was observed in untransformed colonies only after prolonged incubation. The level of differential staining readily identified pTAP-transformed mycoplasma colonies and those colonies that were larger in size and stained a darker blue colour were selected for subculture and further studies.

\section{Quantitative RT-PCR}

The levels of phoA mRNA in both pTP and pTAP transformants were normalised to GAPDH gene expression and the relative abundance determined in three transformants produced using each construct. The difference in gene expression relative to GAPDH mRNA in each transformant was determined. The average level of transcription of $p h o A$ in each pTAP and pTP transformant was compared. The levels of $p h o A$ mRNA (mean \pm SEM) were determined in pTAP3 $(12.49 \pm 1.45)$, pTAP4 (10.89 \pm 1.37$)$, pTAP9 (13.41 \pm 1.48$)$, pTP1 $(1.27 \pm 0.05)$,

Table 2 Site of integration of transposon in M. gallisepticum transformants

\begin{tabular}{lll}
\hline Transformant & Gene insertion site & Gene annotation \\
\hline TAP 3 & MGA_0584 & Hypothetical protein \\
\hline TAP 4 & MGA_0519 & $\begin{array}{l}\text { Csn1 family CRISPR-associated } \\
\text { protein }\end{array}$ \\
\hline TAP 9 & MGA_0906 & Subtilisin-like serine protease \\
\hline TP 1 & MGA_0552 & Hypothetical protein \\
\hline TP 4 & MGA_0554 & Hypothetical protein \\
\hline TP 6 & MGA_0816-0817 & Hypothetical protein \\
\hline
\end{tabular}


pTP4 $(1.51 \pm 0.17)$ and pTP6 $(1.88 \pm 0.06)$. The mean level of $p h o A$ transcription in pTAP transformants $(12.09 \pm 0.74)$ was significantly greater $(P<0.05$, student's $t$-test) than in pTP transformants $(1.55 \pm 0.17)$.

\section{Detection and quantitation of alkaline phosphatase activity in PTAP and pTP transformants}

Five randomly selected pTAP and pTP transformants were selected and their level of alkaline phosphatase expression determined. The level of AP activity in untransformed cells was used as a baseline. The mean level $( \pm$ SEM) of AP activity for 5 pTAP transformants was $190 \pm 8 \mathrm{U} / \mathrm{mg}$ total cell protein, whilst no AP activity was detected in PTP transformants and untransformed cells.

\section{Alkaline phosphatase expression localized to the plasma membrane}

Whole cell proteins from pTAP and pTP transformants were subjected to Western blotting and immunostained using a MAb to alkaline phosphatase. Only in those M. gallisepticum transformed with pTAP, and not in those transformed with pTP, was an immunoreactive $47 \mathrm{kDa}$ band observed, indicating PhoA expression. The protein expression of different pTP or pTAP transformants was similar, and the AP expression of representative transformants TAP3 and TP1 are shown in the results.

Whole cell proteins of untransformed, pTPtransformed or pTAP-transformed $M$. gallisepticum were subjected to Triton X-114 fractionation and proteins in the hydrophobic and aqueous fractions were separated by SDS-PAGE, transferred to PVDF membranes and immunostained using a MAb to alkaline phosphatase. A band of $47 \mathrm{kDa}$, corresponding to the predicted molecular weight of expressed PhoA, was observed in the pTAP-transformed whole cell proteins (Figure 2A, TAP, W) and the hydrophobic fraction (Figure 2A, TAP, H), but not in the aqueous fraction
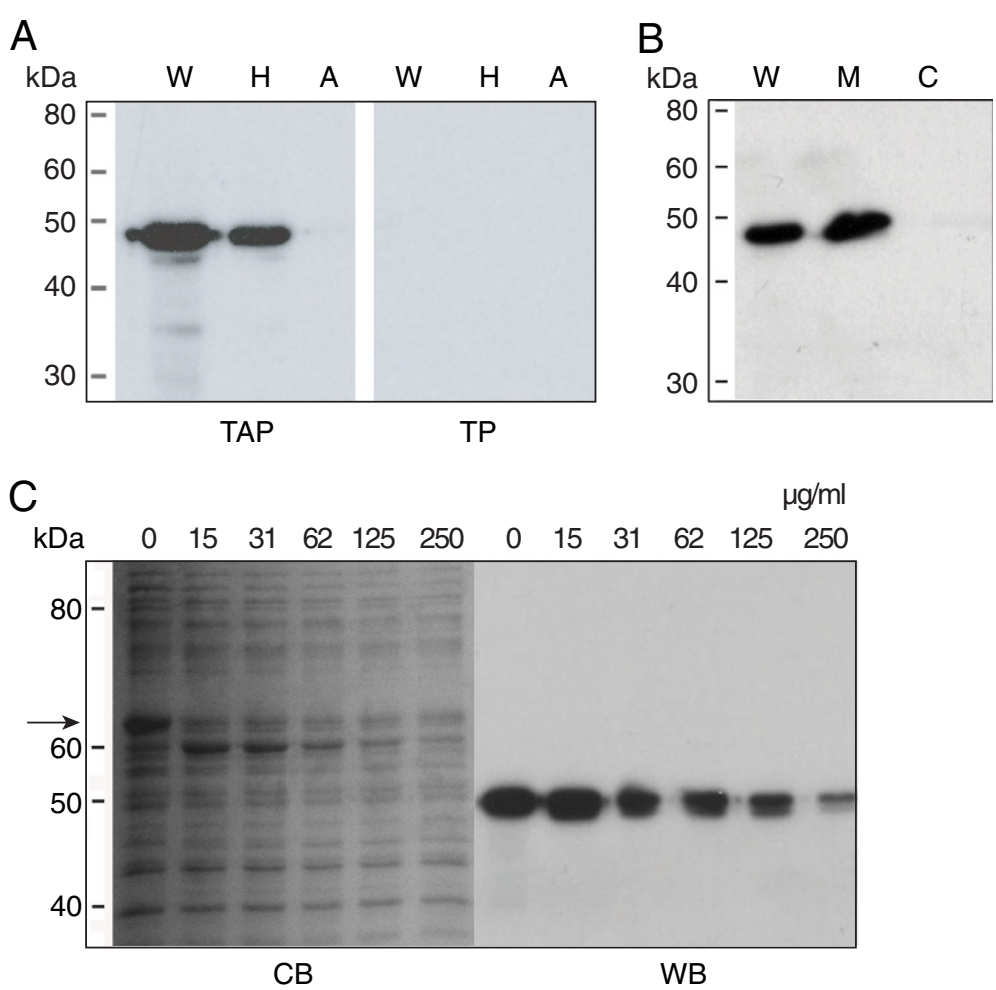

Figure 2 Immuno-detection of PhoA in fractionated or trypsin treated cellular proteins. A. Triton X-114 partitioning of M. gallisepticum cell proteins. Proteins of PTAP or PTP transformed cells were separated into hydrophobic and aqueous fractions by Triton X-114 partitioning, Western transferred and probed with a MAb to alkaline phosphatase. Panel TAP, M. gallisepticum transformed with pTAP and expressing PhoA. Panel A, M. gallisepticum transformed with pTP cells. Lanes W, whole-cells; H, hydrophobic fraction; A, aqueous fraction. B. Immunostaining of cytosolic and membrane fractions of mycoplasma transformants expressing alkaline phosphatase. The fractions were separated on $10 \%$ SDS-polyacrylamide gels, Western transferred and immunostained using a MAb to alkaline phosphatase. Lanes W, whole cells; M, membrane fraction and C, cytosolic fraction. C. Surface proteolysis of PhoA. Whole pTAP transformant cells were treated with increasing concentrations of trypsin, the proteins then separated on $10 \%$ SDS-polyacrylamide gels, Western transferred and immunostained using a MAb to AP. Trypsin concentrations ( $\mu \mathrm{g} / \mathrm{ml})$ are indicated above each lane. Panels CB, Coomassie brilliant blue stained; WB, Western blot probed with MAb to AP. The arrow indicates the $67 \mathrm{kDa}$ VIhA, which was degraded by increasing concentrations of trypsin. The tryptic products of VIhA can also be seen. Most cellular proteins were minimally affected. 
(Figure 2A, TAP, A). No reactivity was observed in any of the fractions from pTP-transformed (Figure 2A, TP, W, H, A) or untransformed M. gallisepticum cells.

Proteins from $M$. gallisepticum transformed with pTAP were separated into membrane and cytosolic fractions by differential ultracentrifugation and the fractions subjected to SDS-PAGE and Western blotted. Immunostaining with a MAb to alkaline phosphatase detected reactivity in both whole cells (Figure $2 \mathrm{~B}, \mathrm{~W}$ ) and the membrane fraction (Figure 2B, M), but not in the cytosolic fraction (Figure 2B, C). As a control, MAb 86 [29], against the VlhA membrane lipoprotein, was also used to probe the blot and detected VlhA in both whole cell proteins and in the membrane fraction, but not in the cytosolic fraction (results not shown).

\section{Trypsin digestion of surface exposed alkaline phosphatase}

The cell surface exposure of M. gallisepticum proteins and AP were examined by trypsin proteolysis. On the Coomassie blue stained SDS-PAGE gel, the concentration of the major cell surface lipoprotein VlhA decreased with increasing concentrations of trypsin and tryptic products of this lipoprotein could be seen (Figure 2C, $\mathrm{CB})$. Immunostaining of trypsin-treated cell proteins with a MAb to alkaline phosphatase demonstrated a gradual loss of reactivity with increasing concentrations of trypsin from $31 \mu \mathrm{g} / \mathrm{ml}$ to $250 \mu \mathrm{g} / \mathrm{ml}$ (Figure $2 \mathrm{C}$, WB), indicating surface exposure of PhoA. As a control, MAb 86 to VlhA was used to confirm tryptic proteolysis of the surface-exposed VlhA lipoprotein (results not shown). The majority of the proteins detectable by Coomassie blue staining were not affected by trypsin treatment, indicating that cytoplasmic proteins were not exposed to proteolysis.

\section{Globomycin inhibited PhoA processing}

When pTAP transformant cells were grown with increasing concentrations of globomycin, cell growth was inhibited. A concentration of $25 \mu \mathrm{g}$ globomycin $/ \mathrm{ml}$ was the highest to still allow growth of cells. Growth in $25 \mu \mathrm{g}$ globomycin $/ \mathrm{ml}$ resulted in an increase in the molecular weight of PhoA (Figure 3A, lane $25 \mu \mathrm{g} / \mathrm{ml}$ ) compared to that seen in cells grown in the absence of globomycin (Figure 3A, lane $0 \mu \mathrm{g} / \mathrm{ml}$ ).

\section{Radiolabelling of lipid modified proteins}

Lipoproteins of M. gallisepticum transformed with pTAP were radiolabelled with $\left[{ }^{14} \mathrm{C}\right]$ palmitate, separated by SDS-PAGE gel and either stained with Coomassie brilliant blue (Figure 3B, CB) and autoradiographed (Figure 3B, RL) or Western transferred and immunostained (Figure 3B, WB). Following autoradiography, a band of $47 \mathrm{kDa}$, similar to the expected size of alkaline phosphatase, was detected in the pTAP transformed cells (Figure 3B, RL, 2), suggesting that PhoA in pTAP transformed M. gallisepticum was a lipoprotein. A Western blot immunostained with a MAb to AP demonstrated the presence of a recombinant AP protein of similar size to that of the radiolabelled band in pTAPtransformed M. gallisepticum (Figure 3B, WB, 2).
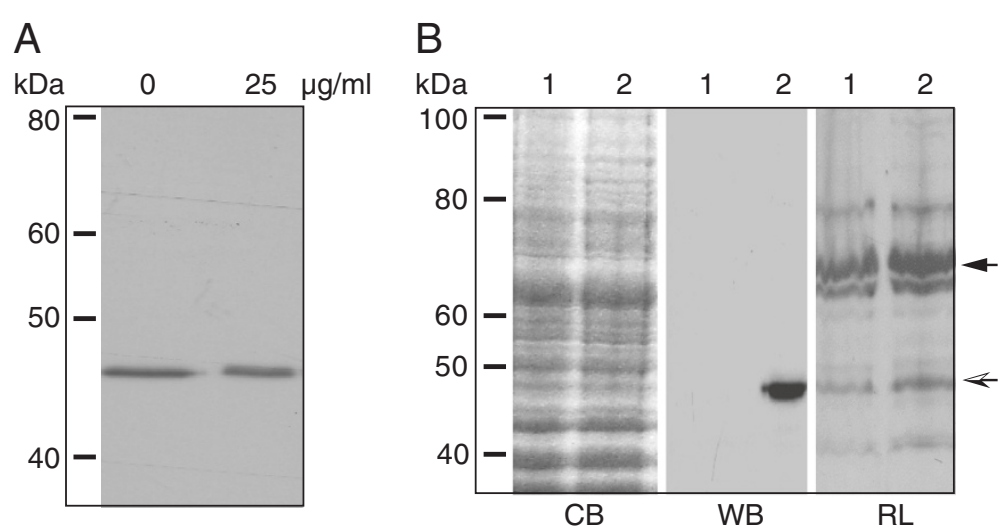

Figure 3 Lipoprotein processing of PhoA. A. Effect of globomycin on the processing of PhoA. Mycoplasma transformants were grown in broth without or with globomycin added, as indicated above each lane, and their proteins separated on $10 \%$ SDS-polyacrylamide gels, Western transferred and immunostained using a MAb to AP. In cells grown in globomycin $(25 \mu \mathrm{g} / \mathrm{ml})$, and thus in which signal peptidase II was inhibited, a higher molecular weight band was seen, indicative of the presence of the prolipoprotein. In the absence of globomycin $(0 \mu \mathrm{g} / \mathrm{ml})$ the fully processed $47 \mathrm{kDa}$ lipoprotein is seen. B. Radiolabelling of PhoA. M. gallisepticum cell proteins and PTAP transformed M. gallisepticum cells were radiolabelled with $\left[{ }^{14} \mathrm{C}\right]$ palmitate and separated on $10 \%$ SDS-polyacrylamide gels. The polyacrylamide gels were stained with Coomassie brilliant blue and autoradiographed or Western transferred and immunostained using a MAb to AP. Lanes 1, M. gallisepticum cells; 2, pTAP transformed cells. Panels CB, Coomassie brilliant blue stained; WB, Western transferred and immunostained; RL, radiolabelled and autoradiographed. The dark arrow indicates the $67 \mathrm{kDa}$ VlhA protein and the open arrow indicates the $47 \mathrm{kDa}$ protein. 
Two-dimensional gel electrophoresis and mass spectrometric analysis of PhoA proteins

Following separation of Triton X-114 preparations of protein by 2-D gel electrophoresis, a spot corresponding to PhoA was excised, digested with trypsin and analysed by mass spectrometry. Peptide mass fingerprinting resulted in the positive identification of PhoA, with a Mascot score of 191 and sequence coverage of $53 \%$ (Figure 4). Potential (unmodified) amino-terminal tryptic peptides (MKRKNILKFISLLGIGSFVMLAAASCTTPVLENR, CTTPVLENR or SCTTPVLENR) were not identified. Attempts to recover the acylated peptide in organic extracts of the gel spot were also unsuccessful.

\section{Discussion}

In this study we used the transposon Tn4001-based vector pISM2062.2lac, modified to form pISM2062.2ltufacyphoA, to transform $M$. gallisepticum and express functional alkaline phosphatase on the cell surface. Two constructs containing the alkaline phosphatase gene, one with the $v l h A 1.1$ leader and acylation sequences and another without these sequences, were introduced into the Tn4001 transposon arm. Following transformation and immunoblotting, a $47 \mathrm{kDa}$ protein was detected in constructs containing the $v l h A 1.1$ leader and acylation sequence. The $v l h A$ acylation sequence was chosen with the purpose of expressing the recombinant protein as a lipoprotein.

To confirm the processing of PhoA as a lipoprotein, radiolabelling and globomycin treatment of mycoplasma cells were carried out. In M. gallisepticum, lipoproteins are predicted to be processed by signal peptidase II, as no other protein processing pathways are known to be present. Processing of lipoproteins by signal peptidase II is specifically inhibited by globomycin and, consequently, processing into a mature lipopeptide is reduced. The increased size of PhoA in cells grown in the presence of globomycin suggests that the VlhA signal sequence was not processed, resulting in an unacylated preprotein. Metabolic labelling of mycoplasmas can be problematic because of the requirement for serum in media, which results in low incorporation of lipids in radiolabelled cells [30]. The presence of other lipoproteins of similar molecular weight that can be labelled with palmitic acid [31] can interfere with specific detection of radiolabelled proteins in SDS-PAGE gels. While it potentially offers greater specificity, detection in 2-D gels was problematic because of the low efficiency of label incorporation, the low abundance of PhoA and the limited loading capacity of 2-D gels, which are likely to have contributed to our inability to detect radiolabelled PhoA after 2-D gel electrophoresis.

Alkaline phosphatase activity was not detected in TP transformants. AP of E. coli has two identical subunits, which fold as monomers and then form dimers for enzymatic activity. In $E$. coli, the proteins thioredoxin reductase (TrxB) and thio-disulfide isomerase (Dsb) maintain the reduced state during export of the protein across the cytoplasmic membrane [32]. It is translocated across the membrane via a Sec-dependent pathway to

\footnotetext{
${ }^{1}$ MKRKNI LKF ISLLGIGSFVMLAAASCTTPVLENRAAQGDITAPGGARRLT

${ }^{51}$ GDQTAALRDSLSDKPAKNI I LLI GDGMGDSEITAARNYAEGAGGFFKGID

${ }^{101}$ ALPLTGQYTHYALNKKTGKPDYVTDSAASATAWSTGVKTYNGALGVDIHE

${ }^{151}$ KDHPTILEMAKAAGLATGNVSTAELQDATPAALVAHVTSRKCYGPSATSE

${ }^{201}$ KCPGNALEKGGKGSITEQLLNARADVTLGGGAKTFAETATAGEWQGKTLR

${ }^{251} \underline{\text { EQAQARGYQLVSDAASLNSVTEANQQKPLLGLFADGNMPVRWLGPKATYH }}$

${ }^{301}$ GNIDKPAVTCTPNPQRNDSVPTLAQMTDKAIELLSKNEKGFFLQVEGASD

${ }^{351} \mathrm{KQDHAANPCGQIGETVDLDEAVQRALEFAKKEGNTLVIVTADHAHASQ} \mathrm{IV}$

${ }^{401}$ APDTKAPGLTQALNTKDGAVMVMSYGNSEEDSQEHTGSQLRIAAYGPHAA

${ }^{451}$ NVVGLTDQTDLFYTMKAALGLK
}

\begin{tabular}{|l|l|}
\hline R.AAQGDITAPGGAR.R & K.TYNGALGVDIHEKDHPTILEMAK.A \\
\hline R.AAQGDITAPGGARR.L & K.AAGLATGNVSTAELQDATPAALVAHVTSR. K \\
\hline R.LTGDQTAALR.D & K. GGKGSITEQLLNAR.A \\
\hline R.LTGDQTAALRDSLSDKPAK. N & K. TFAETATAGEWQGK.T \\
\hline K.NIILLIGDGMGDSEITAAR.N & K.TFAETATAGEWQGKTLR.E \\
\hline R.NYAEGAGGFFK. G & K.TLREQAQAR. G \\
\hline K.GIDALPLTGQYTHYALNK. K & K.ATYHGNIDKPAVTCTPNPQR.N \\
\hline K.TGKPDYVTDSAASATAWSTGVK. T & R. IAAYGPHAANVVGLTDQTDLFYTMK.A \\
\hline
\end{tabular}

Figure 4 Identification of PhoA by mass spectrometry. A tryptic digest of the 2-D gel spot was analysed by MALDI-TOF to obtain a 'peptide mass fingerprint' that was subsequently searched against the NCBI database (Taxonomy= Bacteria). The only significant matches were to AP sequences. The sequence shown is PhoA, and the matched peptides are underlined. The predicted signal peptide is double underlined. The 16 matched peptides are shown in the table below. 
the periplasmic side of the cytoplasmic membrane, the leader peptide is cleaved and the mature alkaline phosphatase is released into the periplasm [33]. Homologous proteins must have been present to enable the folding and export of functional PhoA in pTAP-transformed $M$. gallisepticum. The absence of detectable alkaline phosphatase expression and activity in pTP-transformed mycoplasma cells could be attributable to the lower level of transcription of phoA together with the possible retention of the protein in the cytoplasm in a reduced form, and thus inactive, and subsequent proteolysis. Since the promoter region and all other sequences preceding the start codon were identical to those in PTAP, similar levels of transcription were expected for both constructs, but there was an eight-fold lower level of phoA in pTP transformed cells compared to in those transformed with pTAP. It is not clear whether the signal sequence in the pTAP construct could have affected transcription and further studies are needed to elucidate the mechanisms for the lack of PhoA activity in pTP transformants.

Generally the differences in the protein export pathway of Gram-positive bacteria result in low phoA activity when it is introduced into these organisms [34]. This has led to the use of the Enterococcus faecalis-derived phoZ as a reporter system in Gram-positive bacteria [35]. Although mycoplasmas have similarities to Grampositive bacteria, this study has shown that $p h o A$ from E. coli can be expressed as a membrane protein in $M$. gallisepticum.

As the construct could be successfully introduced into M. galliseptcium using the transposon Tn4001, it could provide a suitable model for investigating membrane protein export in other mycoplasma species. Other workers have investigated the use of TnphoA to detect membrane protein export signal sequences from genomic libraries of mycoplasmas, after introduction into $E$. coli $[13,36]$. The pTAP vector will be a valuable and versatile tool for studies analysing regulatory effects of promoter regions, gene expression using different translational start codons and leader sequences and also for optimising expression of foreign antigens. Studies on gene regulation could also be facilitated by using the PhoA vector.

Mycoplasma lipoproteins are surface exposed and have atypical acylation, and are commonly immunodominant. Thus expression of an antigen as a lipoprotein is likely to be an optimal approach to inducing a vaccinal response [37]. Heterologous lipoprotein expression has been demonstrated in mycoplasmas and its use as live vaccine was emphasized in Mycoplasma capricolum subsp. capricolum, in which spiralin has been expressed on the cell surface using an oriC plasmid vector [38]. The $p h o A$ vector we have described here could be used to facilitate optimisation of expression of heterologous bacterial or viral antigens, and immunomodulators on the mycoplasma cell surface. Preliminary studies in our laboratory using the $p h o A$ vector have been successful in expressing the immunomodulatory genes of chicken IFN- $\gamma$ in the ts- 11 vaccine strain [39]. The expression of such immunomodulatory genes has the potential to enhance the immunogenicity of live attenuated vaccines by intrinsic adjuvantation. The pho $A$ expression system allows rapid assessment of the level of expression from different promoter and signal sequences and thus optimisation of both expression and translocation of such heterologous proteins.

\section{Conclusions}

This is the first study to express alkaline phosphatase on the mycoplasma cell surface. The use of this system will enable us to further study protein translocation across mycoplasma membranes. The study also demonstrates the ease of using phoA as a reporter gene in mycoplasmas. Thus, we have successfully developed a vector system in mycoplasmas with the potential for use in optimising heterologous gene expression and ultimately in recombinant vaccine development, in addition to its potential as used as a tool in studies of the molecular pathogenesis of mycoplasmosis.

\section{Methods}

\section{Bacterial strains and culture conditions}

M. gallisepticum strain S6 was grown in mycoplasma broth (MB) or on mycoplasma agar (MA; containing $1 \%$ agar (Oxoid) without phenol red) at $37{ }^{\circ} \mathrm{C}$ [29]. For selection of mycoplasma transformants, $16 \mu \mathrm{g}$ of gentami$\mathrm{cin} / \mathrm{ml}$ (Invitrogen) was added to the media.

E. coli $\mathrm{DH} 5 \alpha$ cells were used as the host for genetic manipulation and cloning of plasmids. Clones were grown in Luria-Bertani broth (LB) or on LB agar plates (LB with $1 \%$ agar) containing $100 \mu \mathrm{g}$ ampicillin $/ \mathrm{ml}$ (Amresco) at $37{ }^{\circ} \mathrm{C}$. For detection of alkaline phosphatase activity in transformants grown on solid media, the substrate 5-bromo-4-chloro-3-indolyl phosphate (BCIP) (Sigma) was added to the LB agar plates or MA to a final concentration of $40 \mu \mathrm{g} / \mathrm{ml}$.

\section{Amplification of DNA sequences by PCR}

PCR was carried out using Platinum HiFi Taq DNA polymerase (Invitrogen) in a $25 \mu \mathrm{l}$ volume containing $2.5 \mu \mathrm{l}$ of $10 \mathrm{x}$ buffer (Invitrogen), $2 \mathrm{mM} \mathrm{MgSO}_{4}, 100 \mu \mathrm{M}$ of each deoxynucleotide triphosphate (Bioline), $0.4 \mu \mathrm{M}$ of each primer, $1.5 \mathrm{U}$ of enzyme and $5 \mathrm{ng}$ of each PCR product as template. The reaction was performed in an iCycler (BioRad) with an initial cycle of $95{ }^{\circ} \mathrm{C}$ for $3 \mathrm{~min}$, followed by 35 cycles of $94{ }^{\circ} \mathrm{C}$ for $30 \mathrm{~s}, 60{ }^{\circ} \mathrm{C}$ for $30 \mathrm{~s}$ 
and $72{ }^{\circ} \mathrm{C}$ for $1 \mathrm{~min} / \mathrm{kb}$, with a final extension at $72{ }^{\circ} \mathrm{C}$ for $7 \mathrm{~min}$.

\section{Development of alkaline phosphatase construct}

The E. coli phoA gene lacking a promoter, signal sequence and the first 5 residues of the mature protein [28] was cloned under the control of the ltuf promoter and fused to the lipoprotein acylation signal sequence of $v l h \mathrm{~A} 1.1$, and subsequently cloned into the Tn4001 transposon contained in pISM2062.2 to generate the plasmid, pISM2062.2ltufacyphoA (pTAP) (Figure 1A). Another plasmid (pTP), lacking the signal and acylation sequence (pTP), was also produced (Figure 1B).

The pTAP and pTP constructs were introduced into E. coli $\mathrm{DH} 5 \alpha$ by electroporation using a Gene Pulser (BioRad) with settings of $2.5 \mathrm{kV}$ and $25 \mu \mathrm{F}$. Recombinants were selected for ampicillin resistance and clones were screened for the presence of the gentamicin resistance gene using the oligonucleotide primers $\mathrm{GmF}$ and GmR. Selected clones were cultured in larger volumes and plasmid DNA extracted using a Midi prep kit (Qiagen) according to the manufacturer's instructions.

\section{Transformation of M. gallisepticum}

M. gallisepticum was transformed by electroporation as described previously $[39,40]$. Following electroporation, cells were gently resuspended in $1 \mathrm{ml}$ of ice-cold $\mathrm{MB}$, incubated at $37{ }^{\circ} \mathrm{C}$ to allow expression of the gentamicin resistance gene, then a $500 \mu \mathrm{l}$ aliquot of the culture inoculated onto MA plates containing $16 \mu \mathrm{g}$ of gentami$\mathrm{cin} / \mathrm{ml}$, which were allowed to dry and then incubated at $37{ }^{\circ} \mathrm{C}$ for 4 days. The plates were examined for colony development and single colonies selected and subcultured in MB containing $16 \mu \mathrm{g}$ of gentamicin $/ \mathrm{ml}$.

\section{Detection of alkaline phosphatase activity on MA plates}

To detect alkaline phosphatase activity in colonies of transformed $M$. gallisepticum on MA plates, a single tablet of BCIP/nitroblue tetrazolium (NBT) (Sigma Fast, Sigma) was dissolved in $3 \mathrm{ml}$ distilled water and sprayed onto the colonies uniformly as a thin layer using a pump atomizer. After $10 \mathrm{~min}$ colonies were observed for the presence of a blue colour.

\section{Genomic DNA sequencing}

To determine the insertion site of the transposon, genomic DNA sequencing was carried out using the ABI Prism BigDye Terminator v3.1 (BDT) sequencing system (Perkin Elmer Applied Biosystems) and the UBR oligonucleotide primer (Table 1) according to the manufacturer's instructions, with minor modifications. Approximately $2 \mu \mathrm{g}$ of genomic DNA was combined with $1 \mu \mathrm{M}$ of the UBR oligonucleotide, $4 \mu \mathrm{l}$ of the BDT enzyme mixture, $4 \mu$ of $5 \times$ BDT buffer and distilled water to $20 \mu \mathrm{l}$. The sequencing reaction mixture was incubated at $96{ }^{\circ} \mathrm{C}$ for $5 \mathrm{~min}$, then through 60 cycles of $96{ }^{\circ} \mathrm{C}$ for $30 \mathrm{~s}, 50{ }^{\circ} \mathrm{C}$ for $10 \mathrm{~s}$ and $60{ }^{\circ} \mathrm{C}$ for $4 \mathrm{~min}$ in an iCycler thermocycler (BioRad). The sequencing products were purified according to the manufacturer's instructions using ethanol-EDTA-sodium acetate precipitation and analysed using an ABI3100 capillary sequencer.

\section{Quantitative RT-PCR}

Quantitative RT-PCR (qRT-PCR) was used to determine the level of transcription of the phoA gene in each of the transformants. To achieve this, total RNA from $6 \mathrm{ml}$ of transformant cells was extracted using an RNA purification kit (Qiagen), following the manufacturer's instructions. The total amount of RNA was determined using an ND-1000 spectrophotometer (NanoDrop). To remove any contaminating DNA, $2 \mu \mathrm{g}$ of extracted RNA was treated with $2 \mathrm{U}$ of DNase I (Invitrogen) in a buffer containing $2 \mu \mathrm{l}$ of $10 \times$ DNase I buffer and RNase-free water in a total volume of $20 \mu \mathrm{l}$ for $15 \mathrm{~min}$ at room temperature. To produce cDNA, $1 \mu \mathrm{g}$ of DNAse Itreated RNA was used. For each $1 \mu \mathrm{g}$ of DNAse Itreated RNA, $50 \mathrm{ng}$ of random hexamers (Invitrogen) and $10 \mathrm{nM}$ of each deoxynucleoside triphosphate (dNTPs, Bioline) were added and the mixture incubated at $65{ }^{\circ} \mathrm{C}$ for $5 \mathrm{~min}$, then immediately cooled on ice. To this, $4 \mu \mathrm{l}$ of $5 \mathrm{x}$ first strand reaction buffer (Invitrogen) and dithiothreitol (Invitrogen) to a final concentration of $0.1 \mathrm{M}$ were added and the mixture incubated at $25^{\circ} \mathrm{C}$ for $2 \mathrm{~min}$, then $1 \mu \mathrm{l}(200 \mathrm{U})$ of Superscript II reverse transcriptase (RT) (Invitrogen) was added and the reaction incubated for $10 \mathrm{~min}$. A negative control (no RT) was also included, with $1 \mu \mathrm{l}$ of RNase-free water substituted for the Superscript II reverse transcriptase. The reverse transcription reactions were incubated at $42{ }^{\circ} \mathrm{C}$ for $50 \mathrm{~min}$. The reaction was stopped by incubation at $70{ }^{\circ} \mathrm{C}$ for $15 \mathrm{~min}$ and the total volume made up to $600 \mu \mathrm{l}$ with nuclease-free water and aliquots stored at $-20{ }^{\circ} \mathrm{C}$. Each qRT-PCR reaction was conducted in a $20 \mu \mathrm{l}$ volume and contained $5 \mu \mathrm{l}$ template cDNA, $10 \mu \mathrm{l}$ of $2 \times$ Platinum SYBR Green qPCR Supermix containing Rox Dye (Invitrogen) and $100 \mathrm{nM}$ each of the PRTF and PRTR primers (Table 1). Reactions were run using a Stratagene MX3000P. Each assay included test cDNA, the no-RT control reaction previously described and a no template control, to which only water was added. The cycling conditions were an initial incubation for $2 \mathrm{~min}$ at $50{ }^{\circ} \mathrm{C}$, followed by $5 \mathrm{~min}$ at $95{ }^{\circ} \mathrm{C}$, then 40 cycles of $95{ }^{\circ} \mathrm{C}$ for $30 \mathrm{~s}$ and $60{ }^{\circ} \mathrm{C}$ for $30 \mathrm{~s}$. Reactions were carried out in triplicate for each sample. Relative quantification of phoA transcription was normalised against transcription from the glyceraldehyde 3-phosphate dehydrogenase 
gene (GAPDH, GeneID: 1090024) using the HLF and HMR primers (Table 1) and the relative level of expression calculated using the delta-delta Ct method [41].

\section{Detection of alkaline phosphatase activity in cultured cells}

Mycoplasma transformants were grown in $10 \mathrm{ml} \mathrm{MB}$ supplemented with gentamicin at $16 \mu \mathrm{g} / \mathrm{ml}$ until an approximate $\mathrm{pH}$ of 7.2 was reached, then pelleted by centrifugation at $20,000 \times \mathrm{g}$ for $20 \mathrm{~min}$ at $4{ }^{\circ} \mathrm{C}$. The cells were resuspended and washed twice in ice-cold $0.05 \mathrm{M}$ Tris, $\mathrm{pH} 8.0$ ( $\mathrm{T}$ buffer) and again centrifuged and washed as before. The cells were finally resuspended in T buffer with $1 \%$ Triton X-100 (ICN) added and incubated for $15 \mathrm{~min}$ at $4{ }^{\circ} \mathrm{C}$. The total protein concentration of the cell lysate was determined in triplicate using a BCA kit (Pierce) following the manufacturer's instructions. To determine the AP activity of each transformant in triplicate, $10 \mu \mathrm{l}$ of the cell lysate was added to reaction buffer ( $1 \mathrm{M}$ Tris, $\mathrm{pH} 8.0,1 \mathrm{mM} \mathrm{MgCl}_{2}$ ) to which $50 \mu \mathrm{l}$ of $2 \mathrm{mM}$ disodium p-nitrophenyl phosphate (pNPP, Calbiochem) in reaction buffer was added and the mixture incubated at $37{ }^{\circ} \mathrm{C}$ for $30 \mathrm{~min}$. The reaction was terminated by addition of $100 \mu \mathrm{l} 2 \mathrm{M} \mathrm{NaOH}$ and the absorbance read at $410 \mathrm{~nm}$ using a spectrophotometer (Labsystems Multiskan MS). In each assay doubling dilutions in triplicate, starting at $12 \mathrm{U}$ of bacterial alkaline phosphatase (BAP, Invitrogen), were made in $\mathrm{T}$ buffer and similarly treated, enabling a standard curve to be constructed. The alkaline phosphatase activity in the BAP dilution series was plotted against absorbance and this used to determine the alkaline phosphatase activity in each sample, which was expressed as BAP U/mg of total cell protein.

\section{SDS-PAGE, Western blotting and immunostaining}

Mycoplasma cell proteins were separated by SDS-PAGE as described previously [42]. The protein concentrations of mycoplasma cells were determined using the Pierce BCA protein assay kit (Thermo Scientific), using bovine serum albumin as the standard, and $10 \mu \mathrm{g}$ of total cell protein was loaded into each well of a polyacrylamide gel. After separation in a $10 \%$ polyacrylamide gel, proteins were transferred onto PVDF membranes and incubated in blocking solution containing $5 \%(\mathrm{w} / \mathrm{v})$ skim milk (Devondale) in PBS with $0.1 \%$ (v/v) Tween 20 (PBS-T) for $2 \mathrm{~h}$ at room temperature on a rocking platform. Following blocking, membranes were washed three times for $5 \mathrm{~min}$ each in PBS-T. Membranes were then incubated for $1 \mathrm{~h}$ with mouse monoclonal antibody (MAb) to alkaline phosphatase (Chemicon) at a 1:5000 dilution in blocking solution. The membranes were washed thrice for $5 \mathrm{~min}$ with PBS-T and incubated with rabbit anti-mouse-horseradish peroxidase (HRPO) conjugate (Dako) for $1 \mathrm{~h}$ at a 1:5000 dilution in blocking solution. This was followed by washing thrice for $5 \mathrm{~min}$ each with PBS-T and bound conjugate was then detected by chemiluminiscence using an ECL Plus kit (GE Healthcare) according to the manufacturer's recommendations. As molecular weight marker, $10 \mu \mathrm{l}$ of biotinylated protein ladder (Cell Signaling Technology) was loaded, and for detection in Western blots, HRP-linked anti-biotin antibody was used.

\section{Partitioning of mycoplasma cell proteins into hydrophobic and aqueous fractions using Triton X-114} Mycoplasma cell proteins from a $20 \mathrm{ml}$ overnight culture were separated into hydrophobic and aqueous fractions using the detergent Triton X-114 (Sigma) [43,44]. The urea solubilised protein fractions were then analysed by SDS-PAGE.

\section{Membrane and cytoplasmic separation}

Membrane and cytoplasmic fractions of M. gallisepticum were purified essentially as previously described for $M$. pneumoniae [45]. The cytosolic and membrane fractions were then analysed by SDS-PAGE and immunoblotting.

\section{Trypsin treatment of intact $M$. gallisepticum transformant cells}

M. gallisepticum cells were cultured and the cell pellet washed in $50 \mathrm{mM}$ Tris, $0.145 \mathrm{M} \mathrm{NaCl}, \mathrm{pH} 7.4$ (TS buffer). This was repeated twice and the cells finally resuspended in $600 \mu \mathrm{l}$ TS buffer, then divided into 6 equal aliquots. A dilution series of trypsin (Sigma) at 250, 125, 62,31 and $15 \mu \mathrm{g} / \mathrm{ml}$ was made in TS buffer and $100 \mu \mathrm{l}$ of each dilution, as well as a control without any trypsin, added to a separate aliquot of cells and these incubated at $37{ }^{\circ} \mathrm{C}$ for $30 \mathrm{~min}$. Digestion was stopped by the addition of $200 \mu \mathrm{l}$ of $0.125 \%$ (w/v) trypsin inhibitor (Sigma). The trypsin-treated cells were collected by centrifugation, resuspended in TS buffer and proteins in the sample separated by SDS-PAGE and either stained with Coomassie brilliant blue or immunoblotted.

\section{Globomycin treatment}

Globomycin is a peptide antibiotic that inhibits the processing of prolipoprotein to mature lipoprotein by signal peptidase II $[46,47]$. Mycoplasma cells were grown in the presence or absence of globomycin (a gift from Dr. M. Inukai, IUHW, Japan), dissolved in methanol. Cells were grown in $\mathrm{MB}$ with $25 \mu \mathrm{g}$ globomycin/ml and the cells were harvested by centrifugation at 20,000 x g for 20 min at $4{ }^{\circ} \mathrm{C}$, washed thrice in PBS and proteins in the sample separated by SDS-PAGE and either stained with Coomassie brilliant blue or immunoblotted. 


\section{Radiolabelling of $M$. gallisepticum lipoproteins}

M. gallisepticum transformants were cultured in $20 \mathrm{ml} \mathrm{MB}$ to $\mathrm{pH} 7.2$ and cells harvested and resuspended in $2 \mathrm{ml}$ of fresh $\mathrm{MB}$ containing $10 \mu \mathrm{Ci}\left[{ }^{14} \mathrm{C}\right]$ palmitate/ml (Perkin Elmer), then incubated at $37{ }^{\circ} \mathrm{C}$ for $18 \mathrm{~h}$. The cells were centrifuged at $8000 \mathrm{~g}$ for $20 \mathrm{~min}$ at $4{ }^{\circ} \mathrm{C}$ and washed in $2 \mathrm{ml}$ PBS. The washing step was repeated three times. The cells were resuspended in $100 \mu \mathrm{l}$ PBS and SDS-PAGE lysis buffer added. Mycoplasma proteins, together with $\left[{ }^{14} \mathrm{C}\right]$ methylated molecular weight markers (Sigma), were separated by SDS-PAGE in a $10 \%$ polyacrylamide gel and fixed in a solution of $10 \%(\mathrm{v} / \mathrm{v})$ glacial acetic acid and $30 \%$ $(\mathrm{v} / \mathrm{v})$ methanol for $30 \mathrm{~min}$. The gel was incubated in EN ${ }^{3}$ HANCE (Life Science Products) according to the manufacturer's instructions, vacuum dried and then exposed to X-ray film (Kodak).

\section{Two-dimensional gel electrophoresis of fractionated mycoplasma cell proteins}

M. gallisepticum cells were harvested and fractionated with Triton X-114 as described above, and the hydrophobic fraction was resuspended in $8 \mathrm{M}$ urea, $2 \%$ CHAPS, $0.5 \%$ IPG buffer (3-10) and $18 \mathrm{mM}$ dithiothreitol (DTT, GE Healthcare). A 125-150 $\mu$ g sample of protein, as estimated using the 2-D-Quant kit (Amersham Biosciences), was subjected to isoelectric focusing (IEF) on $7 \mathrm{~cm}$ strips over the $\mathrm{pH}$ range of 3-10 (GE Healthcare) using the following parameters: rehydration at $30 \mathrm{~V}$ for $6 \mathrm{~h}, 60 \mathrm{~V}$ for $6 \mathrm{~h}$; running at $200 \mathrm{~V}$ for $1 \mathrm{~h}$, $500 \mathrm{~V}$ for $1 \mathrm{~h}, 1000 \mathrm{~V}$ for $1 \mathrm{~h}, 1000-8000 \mathrm{~V}$ for $1 \mathrm{~h}$ and $8000 \mathrm{~V}$ for $1.5 \mathrm{~h}$. After isoelectric focusing the gel strips were equilibrated twice in $6 \mathrm{M}$ urea, $75 \mathrm{mM}$ Tris- $\mathrm{HCl}$, $\mathrm{pH} 8.8,2 \%$ SDS and $30 \%$ glycerol $(65 \mathrm{mM}$ DTT, $0.135 \mathrm{M}$ iodoacetamide) for $15 \mathrm{~min}$ each. Immediately following equilibration and fixing, the IEF strips were transferred onto a $10 \%$ SDS-polyacrylamide gel and fixed in place with $0.5 \%$ agarose containing bromophenol blue. Electrophoresis was carried out at $200 \mathrm{~V}$ for $1 \mathrm{~h}$. The gels were stained with Coomassie brilliant blue.

\section{Mass spectrometry of PhoA}

Following 2-D gel electrophoresis of fractionated cellular proteins of untransformed and TAP- transformed $M$. gallisepticum, the gel images were compared in order to locate the gel spot likely to correspond to PhoA. This spot was excised and subjected to in-gel digestion and peptide mass fingerprint analysis as described previously [48] using an Ultraflex III MALDI TOF/TOF instrument (Bruker Daltonics, Bremen). Spectra were acquired in reflectron mode and calibrated externally using a standard peptide mix (Bruker Daltonics). Proteins were identified using Mascot v 2.2 (Matrix Science) with the following search parameters: database $=$ NCBI, taxonomy $=$ bacteria, enzyme $=$ trypsin, mass tolerance $=30 \mathrm{ppm}$, missed cleavages $=1$, fixed modifications $=$ carbamidomethyl $\quad($ Cys $)$ and optional modifications $=$ oxidation $($ Met $)$.

\section{Competing interests}

The authors declare that they have no competing interests.

\section{Authors' contributions}

I.S.P designed the study, performed the experiments and data analysis, and drafted the manuscript, AK helped with the experiments, CC contributed the Itufsiglac construct, P.D.V and M.D.G performed mass spectrometry identification and analysis and provided suggestions about the manuscript. G.F.B and P.F.M contributed to the study design, analysis, drafting and review of the manuscript. All authors have read and approved the manuscript.

\section{Acknowledgements}

We thank Dr. Masatoshi Inukai (International University of Health and Welfare, Japan) for the kind supply of globomycin and Dr. Kelly Tivendale for the supply of plasmid pVM01::TnphoA. Fundings

I.S.P was supported by an International Postgraduate Research Scholarship and a Melbourne International Research Scholarship from the University of Melbourne.

\section{Author details}

${ }^{1}$ Asia-Pacific Centre for Animal Health, Faculty of Veterinary Science, The University of Melbourne, Parkville, VIC 3010, Australia. ${ }^{2}$ Melbourne Dental School and Bio21 Institute, The University of Melbourne, Parkville, VIC 3010, Australia.

Received: 14 March 2012 Accepted: 4 June 2012

Published: 8 July 2012

\section{References}

1. Razin S, Yogev D, Naot Y: Molecular biology and pathogenicity of mycoplasmas. Microbiol Mol Biol Rev 1998, 62(4):1094-1156.

2. Gibson DG, Benders GA, Andrews-Pfannkoch C, Denisova EA, Baden-Tillson H, Zaveri J, Stockwell TB, Brownley A, Thomas DW, Algire MA, Merryman C, Young L, Noskov VN, Glass JI, Venter JC, Hutchison CA 3rd, Smith HO: Complete chemical synthesis, assembly, and cloning of a Mycoplasma genitalium genome. Science 2008, 319(5867):1215-1220.

3. Lartigue C, Vashee S, Algire MA, Chuang RY, Benders GA, Ma L, Noskov VN, Denisova EA, Gibson DG, Assad-Garcia N, Alperovich N, Thomas DW, Merryman C, Hutchison CA 3rd, Smith HO, Venter JC, Glass Jl: Creating bacterial strains from genomes that have been cloned and engineered in yeast. Science 2009, 325(5948):1693-1696

4. Cleavinger CM, Kim MF, Wise KS: Processing and surface presentation of the Mycoplasma hyorhinis variant lipoprotein VIpC. J Bacterio/ 1994, 176(8):2463-2467.

5. Yogev D, Menaker D, Strutzberg K, Levisohn S, Kirchhoff H, Hinz KH, Rosengarten R: A surface epitope undergoing high-frequency phase variation is shared by Mycoplasma gallisepticum and Mycoplasma bovis. Infect Immun 1994, 62(11):4962-4968.

6. Neyrolles O, Chambaud I, Ferris S, Prevost MC, Sasaki T, Montagnier L, Blanchard A: Phase variations of the Mycoplasma penetrans main surface lipoprotein increase antigenic diversity. Infect Immun 1999, 67(4):1569-1578.

7. Wise KS: Adaptive surface variation in mycoplasmas. Trends Microbiol 1993, 1(2):59-63.

8. Dybvig K, Voelker LL: Molecular biology of mycoplasmas. Annu Rev Microbiol 1996, 50:25-57.

9. Ley DH, Yoder HW Jr: Mycoplasma gallisepticum infection. In Diseases of Poultry, Volume 194. 10th edition. Edited by Calnek BW, Barnes HJ, Beard CW, McDougald LR, Saif YM. lowa: lowa State University Press; 1997: 194-207.

10. Ley DH, Berkhoff JE, McLaren JM: Mycoplasma gallisepticum isolated from house finches (Carpodacus mexicanus) with conjunctivitis. Avian Dis 1996, 40(2):480-483. 
11. Whithear KG: Control of avian mycoplasmoses by vaccination. Rev Sci Tech Off Int Epizoot 1996, 15(4):1527-1553.

12. Papazisi L, Gorton TS, Kutish G, Markham PF, Browning GF, Nguyen DK, Swartzell S, Madan A, Mahairas G, Geary SJ: The complete genome sequence of the avian pathogen Mycoplasma gallisepticum strain R(low). Microbiology 2003, 149(Pt 9):2307-2316.

13. Cleavinger CM, Kim MF, Im JH, Wise KS: Identification of mycoplasma membrane proteins by systematic TnphoA mutagenesis of a recombinant library. Mol Microbiol 1995, 18(2):283-293.

14. Knudtson KL, Minion FC: Construction of Tn4001/ac derivatives to be used as promoter probe vectors in mycoplasmas. Gene 1993, 137(2):217-222.

15. Knudtson KL, Minion FC: Use of lac gene fusions in the analysis of Acholeplasma upstream gene regulatory sequences. J Bacterio/ 1994 176(9):2763-2766

16. Kordias N: Control of gene expression in Mycoplasma gallisepticum, PhD Thesis. Melbourne: The University of Melbourne; 2003.

17. Bassford PJ Jr, Silhavy TJ, Beckwith JR: Use of gene fusion to study secretion of maltose-binding protein into Escherichia coli periplasm. J Bacterio/ 1979, 139(1):19-31.

18. Michaelis S, Guarente L, Beckwith J: In vitro construction and characterization of phoA-lacZ gene fusions in Escherichia coli. J Bacteriol 1983, 154(1):356-365

19. Dhandayuthapani S, Rasmussen WG, Baseman JB: Identification of mycoplasmal promoters in Escherichia coli using a promoter probe vector with Green Fluorescent Protein as reporter system. Gene 1998, 215(1):213-222.

20. Chiu C-J: Protective immune responses to antigens expressed by mycoplasma vectors, PhD Thesis. Melbourne: The University of Melbourne; 2006.

21. Hahn TW, Mothershed EA, Waldo RH 3rd, Krause DC: Construction and analysis of a modified Tn4001 conferring chloramphenicol resistance in Mycoplasma pneumoniae. Plasmid 1999, 41(2):120-124

22. Michaelis S, Hunt JF, Beckwith J: Effects of signal sequence mutations on the kinetics of alkaline phosphatase export to the periplasm in Escherichia coli. J Bacteriol 1986, 167(1):160-167.

23. Manoil C, Mekalanos JJ, Beckwith J: Alkaline phosphatase fusions: sensors of subcellular location. J Bacteriol 1990, 172(2):515-518.

24. Manoil C, Beckwith J: TnphoA: a transposon probe for protein export signals. Proc Natl Acad Sci USA 1985, 82(23):8129-8133.

25. Akiyama $Y$, Ito $K$ : Folding and assembly of bacterial alkaline phosphatase in vitro and in vivo. J Biol Chem 1993, 268(11):8146-8150.

26. Giladi M, Champion Cl, Haake DA, Blanco DR, Miller JF, Miller JN, Lovett MA: Use of the "blue halo" assay in the identification of genes encoding exported proteins with cleavable signal peptides: cloning of a Borrelia burgdorferi plasmid gene with a signal peptide. J Bacteriol 1993, 175(13):4129-4136.

27. Tivendale KA, Allen JL, Ginns CA, Crabb BS, Browning GF: Association of is and iucA, but not tsh, with plasmid-mediated virulence of avian pathogenic Escherichia coli. Infect Immun 2004, 72(11):6554-6560.

28. Inouye H, Barnes W, Beckwith J: Signal sequence of alkaline phosphatase of Escherichia coli. J Bacteriol 1982, 149(2):434-439.

29. Markham PF, Glew MD, Brandon MR, Walker ID, Whithear KG: Characterization of a major hemagglutinin protein from Mycoplasma gallisepticum. Infect Immun 1992, 60(9):3885-3891.

30. Silim A, Kheyar A: Metabolic radiolabelling of Mycoplasma gallisepticum on Vero cells and radioimmunoprecipitation assay. J Immunol Methods 1995, 178(1):53-58.

31. Demina IA, Serebryakova MV, Ladygina VG, Rogova MA, Zgoda VG, Korzhenevskyi DA, Govorun VM: Proteome of the bacterium Mycoplasma gallisepticum. Biochemistry (Mosc) 2009, 74(2):165-174.

32. Bardwell JC, Beckwith J: The bonds that tie: catalyzed disulfide bond formation. Cell 1993, 74(5):769-771.

33. Black MT: Evidence that the catalytic activity of prokaryote leader peptidase depends upon the operation of a serine-lysine catalytic dyad. J Bacteriol 1993, 175(16):4957-4961.

34. Pearce BJ, Yin YB, Masure HR: Genetic identification of exported proteins in Streptococcus pneumoniae. Mol Microbiol 1993, 9(5):1037-1050.

35. Lee MH, Nittayajarn A, Ross RP, Rothschild CB, Parsonage D, Claiborne A Rubens CE: Characterization of Enterococcus faecalis alkaline phosphatase and use in identifying Streptococcus agalactiae secreted proteins. J Bacteriol 1999, 181(18):5790-5799.
36. Yogev D, Watson-McKown R, McIntosh MA, Wise KS: Sequence and TnphoA analysis of a Mycoplasma hyorhinis protein with membrane export function. J Bacterio/ 1991, 173(6):2035-2044.

37. Jan G, Fontenelle C, Le Henaff M, Wroblewski H: Acylation and immunological properties of Mycoplasma gallisepticum membrane proteins. Res Microbiol 1995, 146(9):739-750.

38. Janis C, Lartigue C, Frey J, Wroblewski H, Thiaucourt F, Blanchard A, SirandPugnet P: Versatile use of oriC plasmids for functional genomics of Mycoplasma capricolum subsp. capricolum. Appl Environ Microbiol 2005, 71(6):2888-2893.

39. Muneta Y, Panicker IS, Kanci A, Craick D, Noormohammadi AH, Bean A, Browning GF, Markham PF: Development and immunogenicity of recombinant Mycoplasma gallisepticum vaccine strain ts-11 expressing chicken IFN-gamma. Vaccine 2008, 26(43):5449-5454

40. Hedreyda CT, Lee KK, Krause DC: Transformation of Mycoplasma pneumoniae with Tn4001 by electroporation. Plasmid 1993, 30(2):170-175.

41. Livak KJ, Schmittgen TD: Analysis of relative gene expression data using real-time quantitative PCR and the 2(-Delta Delta $C(T)$ ) Method. Methods 2001, 25(4):402-408

42. Duffy MF, Noormohammadi AH, Baseggio N, Browning GF, Markham PF: Polyacrylamide gel-electrophoresis separation of whole-cell proteins. In Methods in Molecular Biology. Edited by Miles R, Nicholas R. Totowa, New Jersey: Humana Press; 1998:267-277

43. Bordier C: Phase separation of integral membrane proteins in TritonX114 solution. J Biol Chem 1981, 256:1604-1607.

44. Duffy MF, Noormohammadi AH, Baseggio N, Browning GF, Markham PF: Immunological and biochemical characterization of membrane proteins In Methods in Molecular Biology. Edited by Miles R, Nicholas R. Totowa, New Jersey: Humana Press; 1998:279-298. vol. 104.

45. Ladefoged SA, Christiansen G: Mycoplasma hominis expresses two variants of a cell-surface protein, one a lipoprotein, and one not. Microbiology 1998, 144(Pt 3):761-770.

46. Inukai M, Takeuchi M, Shimizu K, Arai M: Mechanism of action of globomycin. J Antibiot (Tokyo) 1978, 31(11):1203-1205.

47. Inukai M, Ghrayeb J, Nakamura K, Inouye M: Apolipoprotein, an intermediate in the processing of the major lipoprotein of the Escherichia coli outer membrane. J Biol Chem 1984, 259(2):757-760.

48. O'Brien-Simpson NM, Pathirana RD, Paolini RA, Chen YY, Veith PD, Tam V, Ally N, Pike RN, Reynolds EC: An immune response directed to proteinase and adhesin functional epitopes protects against Porphyromonas gingivalis-induced periodontal bone loss. J Immunol 2005, 175(6):3980-3989.

doi:10.1186/1471-2180-12-138

Cite this article as: Panicker et al:: A novel transposon construct expressing PhoA with potential for studying protein expression and translocation in Mycoplasma gallisepticum. BMC Microbiology 2012 12:138.

\section{Submit your next manuscript to BioMed Central and take full advantage of:}

- Convenient online submission

- Thorough peer review

- No space constraints or color figure charges

- Immediate publication on acceptance

- Inclusion in PubMed, CAS, Scopus and Google Scholar

- Research which is freely available for redistribution 